Participatory Educational Research (PER)

Special Issue 2015-II, pp., 117-120; 5-7 November, 2015

Available online at http://www.partedres.com

ISSN: $2148-6123$

http://dx.doi.org/10.17275/per.15.spi.2.14

\title{
Simulation as a Phenomenon of Open Education
}

\author{
Oksana FOTINA* $^{*}$ \\ Foreign Languages Department, Perm State Agricultural Academy, Perm, Russia
}

\begin{abstract}
The paper is devoted to the phenomena of open education and describes the experience of large-scale simulation for encouraging the faculty members and students of a higher educational institution to learn academic English and to apply their language knowledge and ability in the quasi-real situation. Since 2010, five conferences were held on the main theme "Information systems and technologies in science and life" in the English language. Each time from eight to ten reports were introduced followed by discussions. Three main competencies that are in demand in almost all modern education systems and in global science - language ability, ability to deal with information, and knowledge in a certain field - were activated. To make a sense of using English, some foreign participants, face-to-face and online, were invited to the conference. The number of participants from the educational institution was eight speakers each conference. Simulation is obeyed a rigorous scenario. To achieve the aim successfully a participant should act in a certain and correct way. The idea of such simulation activities comply with the principles of the open education: person-oriented character, practical orientation of content and joint activities, problematic content and conversational character of interaction in the training process, reflexivity, variability and supporting motivation approach.
\end{abstract}

Keywords: open education, large-scale simulation, information and communication technologies.

\section{Introduction}

Being relatively autonomous structures, higher educational institutions depend on the conformity level of their internal organization to external conditions (Nurullin, Shchelkunov 2010). Social development causes the features of external circumstances that influence education systems all over the world. Modern education system is characterized by three main key points:

- information and communication technologies,

- application-specific knowledge,

- openness.

As the Open Education Consortium says: "sharing is probably the most basic characteristic of education: education is sharing knowledge, insights and information with others, upon which new knowledge, skills, ideas and understanding can be built." Mainly simulation method is used in teaching economics or management courses. But it also can be applied in forming

\footnotetext{
*23 Petropavlovskaya St., Perm 614990 Russia Email: oksanafotina@ gmail.com
} 
competencies of researchers.

Evolution of information and communication technologies contributes to sharing and enhances the openness of communication continuum. However, the openness and accessibility of communication with peers in the field of science and education provoked the selection of an intermediary language that facilitates the process of interaction.

In many universities in the world appeared the mandatory requirement to faculty members to be able to express their ideas in oral and written way at least in one foreign language. As English is comparatively easier to learn and since the English-speaking countries succeeded in promoting their education standards, the English language has become the medium of interaction for various cultures, for many scientific schools. However, non-linguistic students and faculty members are frustrated when they have to learn the language. Another problem is the absence of the necessity for most of students and faculty members to use a foreign language daily. The solution of the problem could be the method of simulation - imitation of various situations for training purposes.

\section{Technology}

As cited in Randall S. Davis (1996) after Jones (1982, pp. 4-5) there are the three essential elements of simulations: (a) Reality of function (participants are assigned roles and are told they must fully accept them both mentally and behaviorally as if they were actually those people); (b) simulated environment (a realistic setting constructed to enhance roleacceptance by utilizing a variety of realia, e.g., in this case, specially printed business cards, time cards, name tags, letterhead, technical support including computers and a fax machine, and memorandums); and (c) structure (the whole action is built around a set of problems or tasks - not invented by the participants but rather evolve as the action progresses).

The paper describes the experience of large-scale simulation for encouraging the faculty members and students of a higher educational institution to learn academic English and to apply their language knowledge and ability in the quasi-real situation. A conference format was chosen as a quasi-real situation. As it demanded long-term preparation and involved many members with different roles, it was named large-scale simulation.

Since 2010, five conferences were held on the main theme "Information systems in science and life" in the English language. Three main competencies that are in demand in modern education system and in science - language ability, ability to deal with information, and knowledge in a certain field - were activated. To make a sense of using English, some foreign participants, face-to-face and online, were invited to the organizing committee and to the conference. Simulation is obeyed a rigorous scenario. To achieve the aim successfully, a participant should act in a certain and correct way. For instance, the report must be accompanied with a presentation that must have a glossary. The glossary was required because the participants represented different fields of science to make their reports comprehensible for everyone. Many other features of a real conference are characteristic for the simulation event. The number of reports was from eight to ten each time with all the attributes of a real conference - organizing committee, programme, oral presentations, discussions and questions. The simulation activities began long before the day of the conference since they demanded careful preparation that started with the appointment of the organizing committee, event scheduling.

The educational institution usually holds two separate conferences for students and faculty 
members each year. The simulation conference combined participants of different occupations. This fact is very important as it expands the interaction space for scientific discussion.

In accordance with the scenario, participants got specific reaction of the environment and recommendations that helped them to validate their activities, skills and knowledge.

\section{Results and Discussions}

At the first conference, only Russian-speaking participants were there, so the situation when the participants had to use English was created artificially and that caused certain problems in communication. To explain some difficult points in a report it was easier to use the native language than a foreign one.

Another negative experience was when the conference was integrated into another event. It resulted in many reports on almost one field of science. Other participants felt uninvolved and bored. There were also many spelling and grammar errors in oral reports and presentations. Using the method of included observation it was established that the advantages of large-scale simulations are accessibility of the event, absence of pressure that occurs in real events, time for reflection, imitation fosters experience of the activities in organizing events of such kind and participating in such events, as well as skill to present reports in English. Inviting foreign participants to simulation conferences is a good way to promote the national culture and national education standards.

Large-scale simulations have some disadvantages that must be taken into account while preparation process: large-scale simulation demands consulting of an English teacher, in order to lower costs, online-conferences are preferable. However, online conferencing via Skype was not very stable; the video signal was lost many times during the event.

Nevertheless, simulations as an interactive method serve the idea of sharing the information based on personal motivation and opening the education systems.

\section{Conclusions}

Psychologically, the large-scale simulation method allows participants to analyze and validate not only their academic language skills, but also their ability to public speaking. The event has become popular with students and faculty members that plan to participate in various international events.

The idea of such simulation activities comply with the principles of the open education: person-oriented character, practical orientation of content and joint activities, problematic content and conversational character of interaction in the training process, reflexivity, variability and supporting motivation approach.

\section{References}

Crookall, D., \& Oxford, R. L. (Eds.). (1990). Simulation, gaming, and language learning. New York: Newbury House.

JALT "95: Curriculum and Evaluation. (1996). Tokyo: The Japan Association for Language Teaching, pp. 313-317. Copyright @ Randall S. Davis. Retrieved from: http://www.esl-lab.com/research/simul.htm 
Jones, K. (1982). Simulations in language teaching. Cambridge: Cambridge University Press.

Nurullin R.A. Education system as reflection of culture and civilization Нуруллин P.A. Система образования как отражение культуры и цивилизации. Retrieved from: http://vml.antat.ru/files/4e\%20Chteniya/Sistema\%20obrazovaniya\%20kak\%20otrajeni e\%20kultury\%20i\%20civilizacii.pdf

Open Education Consortium. Retrieved from: http://www.oeconsortium.org/about-oec/ Shchelkunov M.D., \& Nikolaeva E.M. Education in XXI century: facing new challenges (2010) Щелкунов М.Д. Николаева, Е.М. Образование в XXI веке: перед лицом новых вызовов, -Казань: Казан. гос. ун-т. -рр. 94-107, 156р. 